\title{
MUTAGENESIS DEVELOPMENT OF ACTINOPLANES SP. KCTC 9161 BY N-METHYL- N'-NITRO-N-NITROSOGUANIDINE (NTG) AND SCREENING FOR ACARBOSE PRODUCTION
}

\author{
Do Thi Tuyen ${ }^{\bowtie}$, Nguyen The Duong, Le Thanh Hoang \\ Institute of Biotechnology, Vietnam Academy of Science and Technology \\ $\bowtie$ To whom correspondence should be addressed. E-mail: dttuyen@ibt.ac.vn
}

Received: 15.7.2016

Accepted: 20.12.2016

\section{SUMMARY}

Acarbose has been widely used in the therapy of type II diabetes (non-insulin dependent) because it controls blood sugar contents of patients after meals. Acarbose, a pseudo-oligosaccharide, acts as a competitive $\alpha$-glucosidase inhibitor. Acarbose is produced by the strains of Bacillus, Streptomyces and Actinoplanes sp. The aim of this study was to develop mutagenesis for an Actinoplanes sp. strain and screening for acarbose production. The spores of Actinoplanes sp. KCTC 9161 strain were subjected to be mutated by N-methyl-N'nitro-N-nitrosoguanidine (NTG) for screening and finding mutant strains that were capable of production of higher acarbose (an inhibitor of $\alpha$-glucosidase) higher than wild type strain. Firstly, the original NTG solution was prepared in phosphate buffer $0.05 \mathrm{M}, \mathrm{pH} 6.9$ and the safety concentration of NTG was determined at 5 $\mathrm{mg} / \mathrm{ml}$. Then, the spores were incubated with different NTG amounts and duration. The living colonies were transferred to fermentation medium. The results obtained showed that 15 mutant strains were produced higher acarbose than wild type when used thin layer chromatography method for analysis and comparing with standard acarbose (Sigma). Three cell lines among total tested 15 mutant lines of Actinoplanes sp. KCTC 9161 produced acarbose at a higher level or indicated a higher inhibitory activity toward $\alpha$-glucosidase than the original strain. Enzymatic inhibitory ativity of $\alpha$-glucosidase of three mutant strains (Actinoplanes sp. KCTCL4, L11, L14) was increased 1.3 fold higher than wild type and Actinoplanes sp. KCTC spores were very sensitive to NTG toxic, $98 \%$ spores could not survive at the treatment condition of $50 \mu \mathrm{g}$ NTG for 30 minutes. In addition, an applicable protocol for mutating Actinoplanes sp. using NTG was suggested for further research.

Keywords: Acarbose, Actinoplanes sp. KCTC 9161, N-methyl-N'-nitro-N-nitrosoguanidine, $\alpha$-glucosidase, mutant

\section{INTRODUCTION}

Acarbose is an $\alpha$-glucosidase inhibitor. It was used as a novel therapeutic agent for treating hyperglycemia in non-insulin-dependent diabetes mellitus (NIDDM) (Inoue et al., 1997). The action of acarbose depends on its structure: a compound of acarviosyl and maltose. In which, acarviosyl is core, which is involved in valienamine and 4-amino-4,6dideoxyglucose by $\mathrm{N}$-glycosidic bond. Therefore, acarbose seems to be like a pseudo-oligosaccharide. It acts as the causing agent in a competitive way with oligosaccharides, delays the digestion of starch and is used to reduce postprandial plasma glucose and insulin levels in diabetic patients (Baron et al., 1987). Acarbose has high biological activity, inhibitor of intestinal $\alpha$-glucosidase with $\mathrm{IC}_{50}=11 \mathrm{nM}$ (Caspary, Graf 1979). This reported demonstrated that the affinity of acarbose with intestinal sucrase was much higher (15,000 folds) if compared to sucrose. The acarbose binding resulted in a very stable enzyme/substrate complex. Acarbose is only minimally absorbed from the gastrointestinal tract $(<2 \%)$, and its action is extended throughout the small intestine; it will be metabolized by colonic bacterial enzymes (Lebovitz, 1998).

Acarbose was the first to be identified in the fermentation broth of Actinoplanes sp. SE50 isolated in the form of coffee soil in Kenya last 1960s (Schmidet et al., 1997). The production of acarbose depends on various sources, ie., maltose (Choi, Shin, 
2003) extracts of corn (Wei et al., 2010), monosodium glutamate (Wang et al., 2011). Actinoplanes sp. SE50/110 (Actinoplanes sp. KCTC 9161) produced $1 \mathrm{~g} / 1$ of acarbose and was widely used for researches on the acarbose synthesis gene (Schwientek, 2012; Klein et al., 2013). Acb-gene cluster in Actinoplanes sp. SE50/110 is the acarbose production cluster of 41,323 bp (Accession number Y18523 in GenBank) (Hemker et al., 2001; Schwientek et al., 2012).

N-Methyl-N'-nitro-N-nitrosoguanidine (NTG) has been widely used to induce mutations in bacteria. Because of highly effective chemical, it has been suggested to be the most potent mutagen yet discovered (Moore, 1968). NTG causes the chemical mutagenic process named alkylation. This methylation modifies the $\mathrm{O} 4$ position of thymine, or the O6 position of guanine, which becomes stably maintained when replicated. The mutations caused by this are transitions.

So far, the research about mutagenic process on Actinoplanes sp. in the world is very little. In Viet Nam, we had some mutagenic Actinoplanes sp. VTCC A1779 by NTG. Six of the 60 mutant strains had $\alpha$-glucosidase inhibitor higher three folds than wild strain (Quyen Dinh Thi et al., 2012). Based on this success, in this experiment we used NTG on Actinoplanes sp. KCTC 9161 strain to screen the mutant strains for higher acarbose production. The methods for assessment of acarbose production ability is thin layer chromatography (TLC) and determination of $\alpha$-glucosidase inhibitor activity (Yamaki, Mori, 2006; Mori et al., 2011).

\section{MATERIALS AND METHODS}

\section{Materials and chemicals}

Actinoplanes sp. KCTC 9161 purchased from the Korea collection for type culture. Acarbose standard and NTG were from Sigma (USA); $p$ nitrophenyl- $\alpha$-D-glucopyranoside, $\alpha$-glucosidase, peptone (Biobasic INC, Canada); n-butanol, ethanol, methanol, ethyl acetat, acid fomic, $\mathrm{CaCl}_{2}, \mathrm{CaCO}_{3}$, $\mathrm{KCl}, \mathrm{FeSO}_{4} \cdot 7 \mathrm{H}_{2} \mathrm{O}, \mathrm{K}_{2} \mathrm{HPO}_{4}, \mathrm{KH}_{2} \mathrm{PO}_{4} \cdot 3 \mathrm{H}_{2} \mathrm{O}, \mathrm{MgSO}_{4}$ were purchased from AR Co, China.

\section{Methods}

\section{Activation of cultured Actinoplanes sp. KCTC 9161}

Actinoplanes sp. KCTC 9161 from the tubes was maintained on agar slant containing $(\mathrm{g} / \mathrm{L})$ : glucose 20; peptone 5; $\mathrm{KCl} 0.5 ; \mathrm{K}_{2} \mathrm{HPO}_{4} 1.0 ; \mathrm{MgSO}_{4} .7 \mathrm{H}_{2} \mathrm{O}$ 0.5; and agar, 2.0; pH 7 (Wei et al., 2010)

\section{Inoculum of Actinoplanes sp. KCTC 9161}

Actinoplanes sp. KCTC 9161 was culture sinking after the activation of propagation medium, at $28^{\circ} \mathrm{C}, 200 \mathrm{rpm}, 72$ hours in an incubator shaker. The inoculum medium (CPC) was composed $(\mathrm{g} / \mathrm{l})$ : sucrose 30 ; peptone $2 ; \mathrm{KCl} 0.5 ; \mathrm{MgSO}_{4} .7 \mathrm{H}_{2} \mathrm{O} 0.5$; $\mathrm{FeSO}_{4} .7 \mathrm{H}_{2} \mathrm{O} \quad 0.1 ; \quad \mathrm{KH}_{2} \mathrm{PO}_{4} .3 \mathrm{H}_{2} \mathrm{O} \quad 1 ;$ casein hydrolysate type 1 .

\section{Fermentation of Actinoplanes sp. KCTC 9161}

The MT1 medium (Nguyen et al., 2013) (fermentation medium) was added $5 \%$ of seed varieties of Actinoplanes sp. KCTC 9161, then the bacteria was cultured at $28^{\circ} \mathrm{C}, 200 \mathrm{rpm}$ in 168 hours shaking. The MT1 medium $(\mathrm{g} / \mathrm{L})$ : maltose 50; glucose 30; core powder $15 ; \mathrm{CaCl}_{2} 2.0 ; \mathrm{CaCO}_{3}$ 2.5; monosodium glutamate 1,$0 ; \mathrm{KH}_{2} \mathrm{PO}_{4} \cdot 3 \mathrm{H}_{2} \mathrm{O}$ 1,0. After 168 hours, broth solution was collected and the produced acarbose in culture were checked by TLC with acarbose standard and the activity of enzyme $\alpha$-glucosidase inhibitor was measured.

\section{Thin layer chromatography}

The fermentation broth was centrifuged at $12,000 \mathrm{rpm}, 4^{\circ} \mathrm{C}$ for 10 minutes to remove bacterial cells. Proteins in the culture was precipitated and the supernatant was cleaned by ethanol ( 1 sample: 4 ethanol $\mathrm{v} / \mathrm{v})$ in 30 minutes. The supernatant was separated by centrifugation at $12,000 \mathrm{rpm}, 4^{\circ} \mathrm{C}$ for 10 minutes, and then dropped on TLC silica gel. Thin-layer chromatography was performed on a Merck silica gel 60 F254, 0.25 mm thick with a solvent system $94 \% \mathrm{~A}$ and $6 \% \mathrm{~B}$ (A contain ethyl acetate: methanol $=1: 1$ and $\mathrm{B}$ contain $\mathrm{H}_{2} \mathrm{O}$ : acid formic $=5: 2$ ), then by the color burst slightly acid $\left(10 \% \mathrm{H}_{2} \mathrm{SO}_{4}\right.$ in ethanol) at $121^{\circ} \mathrm{C}$ in 15 minutes.

\section{Determination of $\alpha$-glucosidase inhibition activity}

$\alpha$-Glucosidase cuts the $\alpha-1,4$ glycosides in polysaccharide. It also digests the $\alpha-1,4$ bonds in $p$ nitrophenyl- $\alpha$-D-glucopyranoside. If those bonds in the compounds are digested, $p$-nitrophenyl - a yellow substance, will be released and absorb light at the wavelength of $405 \mathrm{~nm}$.

After centrifugation at $12,500 \mathrm{rpm}, 4^{\circ} \mathrm{C}$ for 15 min, $10 \mu 1$ supernatant of broth sample was mixed 
with $40 \mu \mathrm{l}$ buffer of $0.1 \mathrm{M}$ phosphate $\mathrm{pH} 6.9$ and $100 \mu \mathrm{l}$ of $\alpha$-glucosidase $1 \mu \mathrm{g} / \mathrm{ml}$ solution in experienced wells. In the controlled wells, the $10 \mu \mathrm{l}$ of broth sample was replaced with $10 \mu$ l of buffer. This mixture was incubated at $25^{\circ} \mathrm{C}$ for 10 minutes. Then, $50 \mu \mathrm{l}$ of $5 \mathrm{mM} \quad p$-nitrophenyl- $\alpha$-Dglucopyranoside was added and incubated for 5 minutes. OD measures were performed before and after incubations.

Ability of inhibition of $\alpha$-glucosidase (\%) was difined as.

$$
\% \text { inhibition }=\frac{\Delta A_{C}-\Delta A_{s}}{\Delta A_{C}} \times 100,
$$

Where, $\Delta A_{C}$ is the changing of OD values of controlled sample before and after incubation

$\Delta A_{s}$ is the changing of OD values of experienced sample before and after incubation

\section{Mutation technique}

The mutagen solution was freshly prepared by dissolving NTG in phosphate buffer ( $\mathrm{pH} 7)$. The final concentration of the mutagen solution was 5 $\mathrm{mg} / \mathrm{ml}$ and was kept in dark.

Actinoplanes sp. KCTC 9161 spores were selected from CPC medium (agar or liquid). We collected spores by $0.2 \%$ Tween 20 solution in CPC agar medium, slightly shake in 30 minutes; with CPC liquid medium, we centrifuged the broth in 5 minutes, 8,000 rpm and dissolved again by water.
Spores were incubated with NTG $(50,100,150$ and $200 \mu \mathrm{g}$ for one milliliter of spores). Each NTG concentration was studied in 30,60 and 90 minutes at $25^{\circ} \mathrm{C}$. After incubation, the stopping NTG action was carried out by washing with phosphate buffer, centrifugation in 5 minutes, $8,000 \mathrm{rpm}$. The spore was collected again then repeated 3 times for mutation. Finally, the spores were cultured on CPC agar medium at $25^{\circ} \mathrm{C}$. After 120 hours, the numbers of the colonies raised on agar plates were recorded to compute the survival rates. These mutant strains will be used to ferment and determine the ability of acarbose production.

\section{RESULTS AND DISCUSSION}

\section{The characteristics of Actinoplanes sp. KCTC 9161}

Actinoplanes sp. KCTC 9161 is gram-positive, has fibrous structure, the fibers tightly linked together to form a separate orange-colony, bulging in the middle colonies that developed to sporangia contain spores. Spores can be mobile. The fibrous is just a cell, there is no horizontal septum, simple nuclear, no nuclear membrane. Actinomycetes reproduces by spores, prefers moist, appropriate with $\mathrm{pH} \mathrm{6-8}$ in culture. In agar medium, the colony of Actinoplanes sp. KCTC 9161 strain had round shape, smooth surface, slow development (5-7 days), orange colonies 1-2 $\mathrm{mm}$ in diameter (Fig. 1A). In liquid medium, they grew well, forming circular pellet particles, insoluble when shaken up, orange color (Fig. 1B).

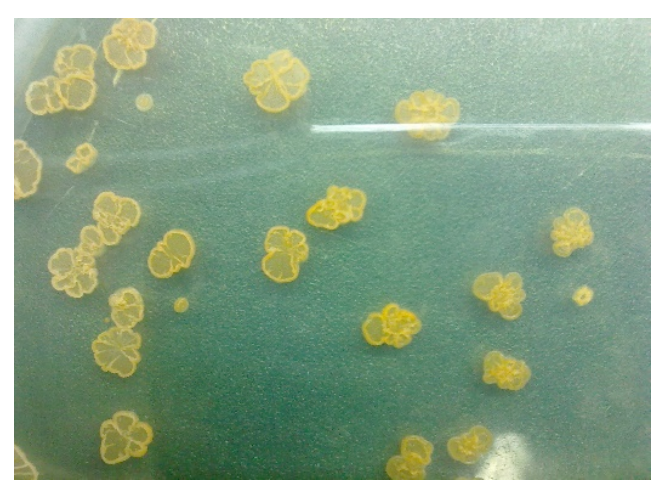

A



B

Figure 1. The colonies of Actinoplanes sp. KCTC 9161 strain (A) in agar medium; (B) in liquid medium 
The acarbose production ability of this strain was expressed on MT1 medium. After 7 days (168 $\mathrm{hrs}$, the fermentation broth was cleaned and acarbose in culture was checked by TLC and $\alpha$ glucosidase inhibitor ability. The TLC result (Fig. 2) exhibited a deep-clearly band, same position in horizontal lines with acarbose standard and $\alpha$ glucosidase inhibition activity was $50 \%$.

\section{The concentration of NTG original solution}

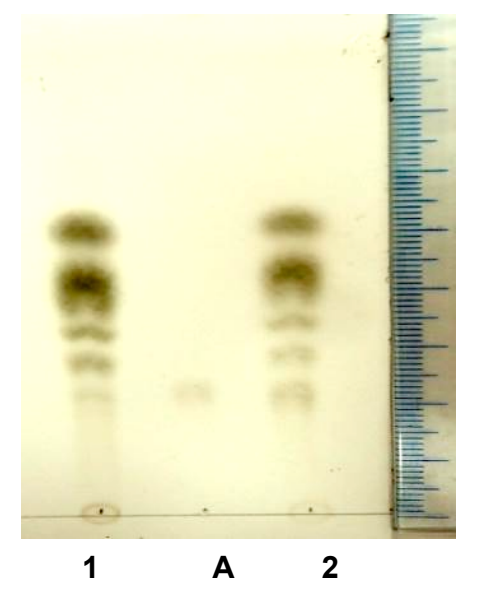

Figure 2. TLC analysis of the acarbose samples from fermentation broth of Actinoplanes sp. KCTC 9161.1,2: fermentation broth; A: acarbose standard (Sigma).
The concentration of original NTG is very important with mutation experiment. If the NTG original solution is not clean, the experiment will fail by infection. In theory, NTG is toxic for bacteria, but in the low concentration of NTG, the organism can be survival. Firstly, $50 \mu 1$ of the $100 \mu \mathrm{g} / \mathrm{ml}$ NTG was used to spread on CPC agar medium for mutation test. After 5 days, a lot of bacteria appeared on agar plate. Other NTG solution was prepared $(5 \mathrm{mg} / \mathrm{ml})$, after 5 days, the agar plate is clean without the attention of bacteria data not show. The NTG concentration of $5 \mathrm{mg} / \mathrm{ml}$ was used for mutation experiment after.

\section{The NTG mutation experiment with liquid spore}

Base on the characteristics of Actinoplanes sp KCTC 9161, the problem about weak growth of this strain can be resolved by spores taking from liquid medium. We can collect high amount of spores which is in the growing process.

Actinoplanes sp. KCTC 9161 was cultured on $\mathrm{CPC}$ liquid medium, $200 \mathrm{rpm}, 28^{\circ} \mathrm{C}, 120$ hours. The spore was collected by centrifugation, removed surfactant, added water to same volume before. Four milliliters of spore in four Eppendorf tubes were treated with 50, 100, 150 and $200 \mu \mathrm{g}$ NTG, respectively. After 30, 60 and 90 minutes, $300 \mathrm{ml}$ of spore were taken out, washed 3 times with phosphate buffer and cultured on CPC agar plate, $100 \mathrm{ml}$ per one plate. The results were shown in Tab. 1.

Table 1. The survival colony in NTG mutation liquid spore

\begin{tabular}{llllllll}
\hline \multirow{2}{*}{$\begin{array}{l}\text { NTG } \\
(\boldsymbol{\mu g})\end{array}$} & Control & \multicolumn{2}{c}{$\mathbf{3 0} \mathbf{m i n}$} & \multicolumn{2}{c}{$\mathbf{6 0} \mathbf{m i n}$} & \multicolumn{2}{c}{$\mathbf{9 0} \mathbf{m i n}$} \\
\cline { 3 - 8 } & & $\begin{array}{l}\text { Number of } \\
\text { living colonies }\end{array}$ & $\begin{array}{l}\text { Survival ratio } \\
(\%)\end{array}$ & $\begin{array}{l}\text { Number of } \\
\text { living colonies }\end{array}$ & $\begin{array}{l}\text { Survival } \\
\text { ratio }(\%)\end{array}$ & $\begin{array}{l}\text { Number of } \\
\text { living colonies }\end{array}$ & $\begin{array}{l}\text { Survival } \\
\text { ratio }(\%)\end{array}$ \\
\hline 50 & $3927 \pm 100.1$ & $620 \pm 12.3$ & 15.8 & $820 \pm 28.1$ & 20.9 & $1072 \pm 84.5$ & 27.3 \\
100 & $3927 \pm 100.1$ & $295 \pm 17.8$ & 7.5 & $514 \pm 45.1$ & 13.08 & $1042 \pm 114.4$ & 26.5 \\
150 & $3927 \pm 100.1$ & $235 \pm 32.1$ & 6.0 & $371 \pm 24.2$ & 9.4 & $838 \pm 29.7$ & 21.3 \\
200 & $3927 \pm 100.1$ & $1098 \pm 67.9$ & 27.9 & $450 \pm 14.6$ & 11.4 & $847 \pm 48.2$ & 21.5 \\
\hline
\end{tabular}

In theory, the survival ability of spore after treatment with NTG depends on the concentration of NTG and the duration of incubation time. With low NTG concentration or short time treatment, the number of survival colony on agar plate will be higher than in plate that was treated with higher concentration of NTG or longer time incubation. The effect of NTG on survival ability of spores was seen clearly when compared the number of colony on control plate with treatment plates. It seemed true with plates in different NTG concentrations. The survival ability of 
spores was decreased when the concentrations of NTG increased. On overall view, the number of colonies on plates that treated with $50 \mu \mathrm{g}$ NTG were highest, higher than plates treated with 100 $\mu \mathrm{g}$ NTG, the next was $150 \mu \mathrm{g}$ and in the end was $200 \mu \mathrm{g}$ NTG. The numbers of colonies were increased with longer treatment time. In 90 minutes of treatment, the number was highest, then in 60 minutes; and those in 30 minutes were smallest.

The number of living colonies was too much for acarbose production faculty. Thus non-control concentration of spores before experiment was the reason for this problem. In other hand, the higher NTG concentration can be used but it will be very dangerous for the researcher. Studying NTG mutation on agar plate was chosen as our solution in the next result.

The problem we have when do mutagenic with spore from liquid medium is the killing effect of NTG is not right with more time treatment. The number of living spore in 90 min treatment with NTG in each concentration are higher than in 60 min and least in $30 \mathrm{~min}$. The result should be reverse, highest number in $30 \mathrm{~min}$, then in $60 \mathrm{~min}$ and last in $90 \mathrm{~min}$ as table 1 with $50 \mu \mathrm{g}$ NTG treatment. The reason caused by the pelleting shape spore of KCTC 9161 strain in liquid medium. The pellet of Actinoplanes sp. KCTC 9161 strain consisted of many spores and the fibrous can link strongly together, making the pellet too hard to be broken when shaking. In experiment process, after shaking to take $300 \mu 1$ spore the pellet is rapidly go down to the bottom. Because the fibrous of pellet are stabilized, they can act as a shield which prevents the toxic of NTG on the spore in deep of a pellet. It means with long time treatment, the amount of pellets we take out is increased and the number of spore will be increased. The solution for the defect of this method is masticated to break pellet shape, and use filter to removing the pellet as possible.

\section{The mutation experiment with agar spore}

Actinolanes sp. KCTC 9161 strain was cultured on CPC agar medium. After 120 hours, two agar plates were used to collecting spore by $10 \mathrm{ml}$ Tween $200,2 \%$ and divided $1 \mathrm{ml}$ spore for 1 Eppendorf tube. The steps to do experiment were the same with experiment on liquid pore.

In this experiment, the result was better than result in the experiment with liquid spore. The number of living colonies on control plate was about 1000 . Thus concentration of living spores was $10^{4} \mathrm{ml}$. The survival ratio of NTG treated -KCTC 9161 spore for each concentration of NTG was indicated in Tab. 2. It's clearly that KCTC 9161 spore is very sensitive with toxic effect of NTG. In just only $30 \mathrm{~min}$ of treatment with $50 \mu \mathrm{g}$ NTG, more than $99 \%$ spores were killed. It's is possible to make the comparison with other bacteria; with a 30 min treatment time only $39 \%$ of Escherichia coli organisms were killed by $300 \mu \mathrm{g}$ NTG/ml (Adelberg et al., 1969), while $80 \%$ of treated organisms of Schizosaccharomyces pombe were killed by exposure to $2 \mathrm{mg} \mathrm{NTG} / \mathrm{ml}$, again for $30 \mathrm{~min}$ (Megnet, 1965). Therefore, KCTC 9161 strain has 200 times more sensitive than $E$. coli and above 400 times more sensitive than $S$. pombe to the killing effect of NTG. Sixteen colonies includes: 4 colonies (named L1, L2, L3, L4) from treatment of NTG 50, $30 \mathrm{~min}, 4$ colonies (named L5, L6, L7, L8) from treatment of NTG 50, $60 \mathrm{~min} ; 4$ colonies (named L9, L10, L11, L12) from treatment of NTG 50, $90 \mathrm{~min}$; 1 colony (named L13) from treatment of NTG 150, $30 \mathrm{~min}, 2$ colonies (named L14, L15) from treatment of NTG 200, 30 min and 1 colony from control were cultured to test acarbose production.

Table 2. The number of living colonies and survival ratio in mutation experiment with agar spore

\begin{tabular}{|c|c|c|c|c|}
\hline \multicolumn{5}{|c|}{ Number of living colonies } \\
\hline Time(min) & 30 & 60 & 90 & Survival ratio (\%) \\
\hline 50 & 63 & 44 & 41 & 0.0148 \\
\hline & $(3+17+43)$ & $(12+10+22)$ & $(30+10+1)$ & $(0.0063+0.0044+0.0041)$ \\
\hline 100 & 0 & 0 & 0 & 0.0000 \\
\hline 150 & 1 & 0 & 0 & 0.0001 \\
\hline 200 & 2 & 0 & 0 & 0.0002 \\
\hline
\end{tabular}


The acarbose production ability of 15 mutation strains

Sixteen strains (15 mutants and 1 normal strain) were cultured on CPC liquid medium to increasing number of spores. After 120 hours, they were transfer to fermentation medium (MT1) at $28^{\circ} \mathrm{C}, 200 \mathrm{rpm}, 168 \mathrm{hrs}$. The fermentation broth was centrifuged at $12,000 \mathrm{rpm}$ for $10 \mathrm{~min}$. The surfactant solution was used to check the acarbose production and inhibitor $\alpha$ glucodidase.

In TLC plate, all cultures from 16 strains made dark bars in the same position with acarbose standard in horizontal (Fig. 3). The inhibitor activity of $\alpha$ glucosidase showed in Fig.4. Base on this result, the strain L4, L11 and L14 had the highest $\alpha$-glucosidase inhibitory activity ( 1.3 folds higher) than control.

The improvement of the high acarbose yielded by the mutant KCTC 9161 strains may be of 3 reasons. The first, Lee et al. (2008) have studied 3 gene clusters of $\operatorname{TreX}-Y-Z$ in Actinoplanes sp. $\mathrm{SN} 233 / 29$. Tre $Y$ was encrypted for an isomerase that can convert acarbose (Ac-1,4-Glc-1,4-Glc) to component C (Ac-1,4-Glc-1,1-Glc). The prevention component $\mathrm{C}$ production is useful in increasing acarbose level in fermentation broth by mutation
TreY gene (Lee et al., 2008). The second, the acarbose production was of the process by 25 genes, encoding for some enzymes and important factors. If the intensity expression or the ability of one gene is increased by mutation, probably the acarbose level would be higher. The last, maltose has important influences on the acarbose production in Actinoplanes sp. A56 (Wei et al., 2010). The amount of acarbose was increased from 837 to $1043 \mathrm{mg} / \mathrm{l}$ with maltose from $30 \mathrm{~g} / \mathrm{L}$ to $61.25 \mathrm{~g} / \mathrm{L}$. Here is only putative reasons, that should be confirmed in future by experiments.

The acarbose production capacity of 15 mutants strains were shown in Fig. 3. Overall, all of strain increased the production of acarbose, presented by the dark of the acarbose band and $\alpha$-glucosidase inhibition (Fig.4). However, the highest inhibitor of acarbose activity (L4, L11, L14) was 1.3 folds higher than control, less than the data resulted from the study of QDT (2012)- 3 times higher than control on Actinoplanes sp. VTCC-A1779. It was impossible to make exactly comparison because some colonies were not tested. We supposed that NTG had effect on improving acarbose production of Actinoplanes sp. KCTC 9161. Based on our experiment, we suggested a protocol to do NTG mutant with Actinoplanes sp. KCTC 9161.

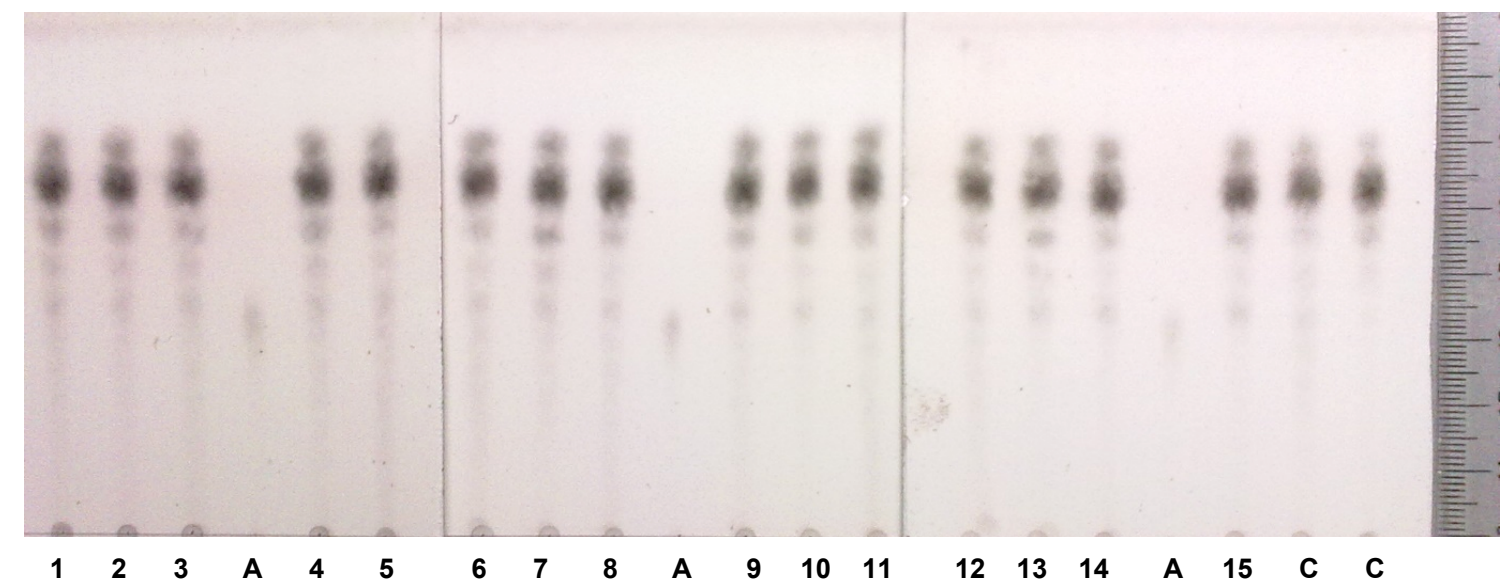

Figure 3. Acarbose production from cultures developed from 16 strains by thin layer chromatography. 1-15: Strain L1-L15; A: acarbose standard $(\mathrm{Rf}=0.41)$; $\mathrm{C}$ : control

We hope this experiment can help some researchers in next study: The Actinoplanes sp. KCTC 9161 strain is cultured on CPC liquid medium at $28^{\circ} \mathrm{C}, 200 \mathrm{rpm}, 120 \mathrm{hrs}$. Transfer $100 \mu \mathrm{l}$ spore in the $\mathrm{CPC}$ agar plate, keep in $120 \mathrm{hrs}, 28^{\circ} \mathrm{C}$. After that, collect the colonies by stick, put in Tween $200.2 \%$ solution, vortex in 30 min to have final concentration of spore about 10000 for $1 \mathrm{ml}$. One milliliter spore is incubate with 50-100 $\mu \mathrm{g}$ NTG (concentration of NTG original $5 \mathrm{mg} / \mathrm{ml}$ phosphate buffer $\mathrm{pH} 6.9,0.5$ 
M) in 30, 60 and 90 min. Stop the action of NTG by washing with phosphate buffer $(\mathrm{pH} 6.9,0.5 \mathrm{M})$, centrifuge at $8000 \mathrm{rpm}$ for $5 \mathrm{~min}$; repeat 3 times. Finally, $100 \mu \mathrm{l}$ spores are cultured on CPC agar. After 5 days, the living ratio of spore is less than $2 \%$ with control.

Each survival colony is transferred to $\mathrm{CPC}$ liquid medium to increasing number of spore, $120 \mathrm{~h}$, $28^{\circ} \mathrm{C}, 200 \mathrm{rpm} .5 \%(\mathrm{v} / \mathrm{v})$ of seed varieties added to fermentation medium, continue in $168 \mathrm{hrs}, 28^{\circ} \mathrm{C}, 200$ rpm. Then, the fermentation broth is centrifuged at $12,000 \mathrm{rpm}, 10 \mathrm{~min}, 4^{\circ} \mathrm{C}$. The surfactant is cleaned by methanol (1 sample: 4 ethanol $(\mathrm{v} / \mathrm{v}))$ in $30 \mathrm{~min}$. After that, centrifuged at $12,000 \mathrm{rpm}, 4^{\circ} \mathrm{C}$ for $10 \mathrm{~min}$ and use surfactant to point on TLC plate. Solvent system is $94 \% \mathrm{~A}$ and $6 \% \mathrm{~B}$ (A contain ethyl acetate: methanol $=1: 1$ and $\mathrm{B}$ contain $\mathrm{H}_{2} \mathrm{O}$ : acid formic $=$ $5: 2 \mathrm{v} / \mathrm{v})$, then dye by slightly acid $\left(10 \% \mathrm{H}_{2} \mathrm{SO}_{4}\right.$ in ethanol) at $121^{\circ} \mathrm{C}$ in 15 minutes. Use surfactant of fermentation broth after centrifuged for $\alpha$ glucosidase inhibitor ability.

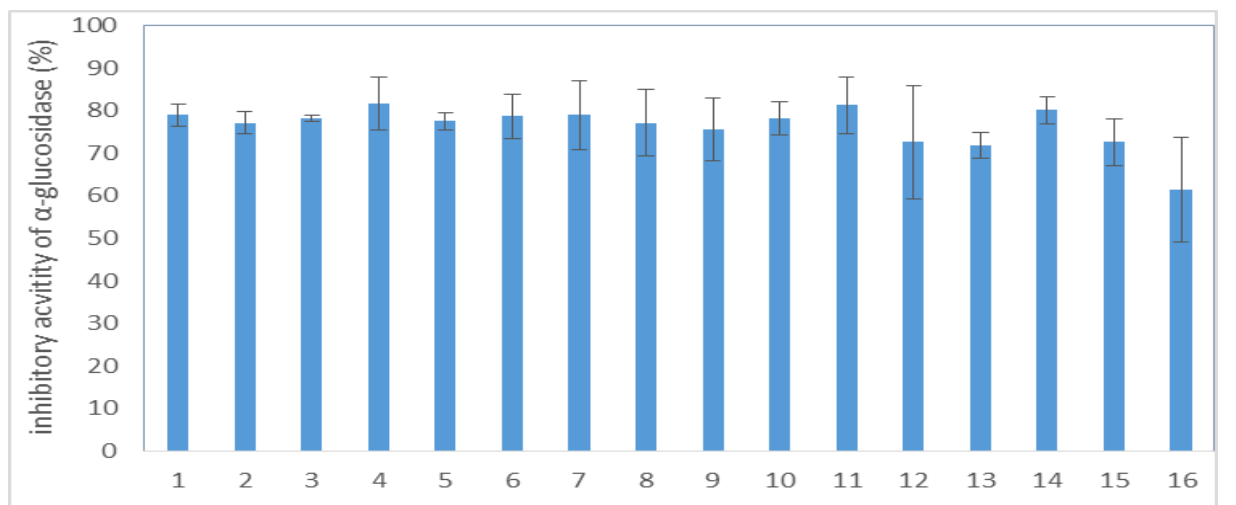

Figure 4. The $\alpha$-glucosidase inhibitor ability of the cultures from 16 strains 1-15: L1-L15; 16: Control

\section{CONCLUSION}

In this experiment, the novel findings were that three mutant strains (Actinoplanes sp. KCTC $9161-$ L4, L11, L14) have $\alpha$-glucosidase inhibitory higher 1.3 times than wild type. It is necessary to build up a good protocol for the next study and to continue to conduct experiments to find which the best mutant strain is.

Acknowledgements: This study was supported by Ministry of Industry and Trade, Vietnam, with the project: "Study on the production of acarbose for treatment of type II diabetes" (2012-2015).

\section{REFERENCES}

Baron AD, Eckel RH, Schmeiser L, Kolterman OG (1987) The effect of short-term a-glucosidase inhibition on carbohydrate and lipid metabolism in type II (noninsulinde- pendent) diabetics. Metabolism 36: 409-415.

Caspary WF, Graf S (1979) Inhibition of human intestinal $\alpha$-glucoside hydrolases by a new complex oligosaccharide. Res Exp Med 175: 1-6.
Choi BT, Shin CS (2003) Reduced formation of byproduct component $\mathrm{C}$ in acarbose fermentation by Actinoplanes sp. CKD485-16. Biotechnol Prog 19(6): 1677-1682.

Hemker M, Stratmann A, Goeke K, Schröder W, Lenz J, Piepersberg W, Pape H (2001) Identification, cloning, expression, and characterization of the extracellular acarbosemodifying glycosyltransferase, AcbD, from Actinoplanes sp. strain SE50. J Bacteriol 183: 4484-4492.

Inoue I, Takahashi K, Noji S, Awata T, Negishi K, Katayama S (1997) Acarbose controls postprandial hyperproinsulinemia in non-insulin dependent diabetes mellitus Diabetes Res Clin Pract 36: 143-151.

Klein A, Selber K, Wehlmann H, Rosen W, Puhler A, Schwientek P, Kalinowski J, Wehmeier UF (2013) New Actinomycete intergrative and conjugative element from Actinoplanes sp. SE50/110 as plasmid for genetic transformation of related Actinobacteria. International Publication Number: WO 2013/083566 A083561.

Lebovitz HE (1998) A-glucosidase inhibitors as agents in the treatment of diabetes. Diabetes Rev 6: 132-145.

Lee JS, Hai T, Pape H, Kim TJ, Suh JW (2008) Three trehalose synthetic pathways in the acarbose-producing Actinoplanes sp. SN223/29 and evidence for the TreY role 
in biosynthesis of component C. Appl Microbiol Biotechnol. 80(5): 767-778.

Moore D (1968) The Mutagenic Action of N-methyl-N'nitro-N-nitrosoguanidine on Coprinus Zagopus. J Gen Microbwl 55 121-125.

Mori Y, Shiozaki M, Matsuura K, Tanaka T, Yokoyama J, Utsunomiya K (2011) Evaluation of efficacy of acarbose on glucose fluctuation and postprandial glucose using continuous glucose monitoring in type 2 diabetes mellitus. Diabetes Technol Ther 13: 467-470.

Nguyen TN, Do TT, Le TH, Quyen ĐT (2013) Effect of medium components on acarbose production by Actinoplanes sp. KCTC-9161. National Conference on Biotechnology 2013. Publisher of Science and Technology: 403-406.

Quyen Dinh Thi, Le Thanh Hoang, Le Thi Trang, Do Thi Tuyen (2012) Enhancing of acarbose production by Actinoplanes VTCC-A1779 mutation strains. Vietnam Journal of Chemistry 50: 113-116.

Schmidet DD, Frommer W, Junge B, Muller L, Wingender W, Truscheit E, Schafer D (1997) Alpha-glucosidase inhibitors new complex oligosaccharides of microbial origin. Die Naturwissenschaften 64: 535-536.

Schwientek P (2012) Genomics and Transcriptomics of the inductrial Acarbose producer Actinoplanes sp. SE50/110. Bielefeld University, Germany: 155.

Schwientek P, Szczepanowski R, Ruckert C, Kalinowski J, Klein A, Selber K, Wehmeier UF, Stoye J, Puhler A (2012) The complete genome sequence of acarbose producer Actinoplanes sp. SE50/110. BMC Genomic 13: 18.

Wang YJ, Liu LL, Feng ZH, Liu ZQ, Zheng YG (2011) Optimization of media composition and culture conditions for acarbose production by Actinoplanes utahensis ZJB08196. Microbiol Biotechnol 27: 2759--2766.

Wei SJ, Cheng X, Huang L, Li KT (2010) Medium optimization for acarbose production by Actinoplanes sp. A56 using the response surface methodology. Academic Journals 9(13): 1949-1954.

Yamaki K, Mori Y (2006) Evaluation of $\alpha$-glucosidase inhibitory activity in colored foods : a trial using slope factors of regression curves. Nippon Shokuhin Kagaku Kogaku Kaishi 53: 229-231.

\title{
GÂY ĐộT BIẾN CHỦNG ACTINOPLANES SP. KCTC 9161 BẰNG N-METHYL-N'- NITRO-N-NITROSOGUANIDINE (NTG) VÀ SÀNG LỌC DÒNG CÓ KHẢ NĂNG SINH ACARBOSE CAO
}

\section{Đỗ Thị Tuyên, Nguyễn Thế Dương, Lê Thanh Hoàng}

Viện Công nghệ sinh học, Viện Hàn lâm Khoa học và Công nghệ Việt Nam

\section{TÓM TẮT}

\begin{abstract}
Acarbose đã được sử dụng rộng rãi trong điều trị bệnh đái tháo đường type 2 không phụ thuộc-insulin. Acarbose là hợp chất hữu cơ giả đường (pseudo-oligosaccharide), hoạt động như một chất ức chế cạnh tranh $\alpha$ glucosidase. Acarbose có thể kiểm soát hàm lượng đường trong máu của bệnh nhân sau khi ăn và được sinh tổng hợp từ các chủng vi sinh vật như Bacillus, Streptomyces và Actinoplanes... Mục đích của nghiên cứu này là gây đột biến chủng xạ khuẩn Actinoplanes sp. và sàng lọc các dòng có khả năng sinh tổng hợp acarbose cao. Bào tử của chủng Actinoplanes sp. KCTC 9161 được gây đột biến bằng NTG (nitrosoguanidine) để tìm ra các dòng đột biến có khả năng sinh tổng hợp acarbose cao hơn chủng gốc. Nồng độ NTG gốc được chuẩn bị là 5 $\mathrm{mg} / \mathrm{ml}$ trong đệm phosphate $\mathrm{pH}$ 6.9. Bào tử được ủ với $\mathrm{NTG}$ nồng độ $50,100,150$ và $200 \mu \mathrm{g}$ trong 30,60 và 90 phút và được nuôi trên môi trường thạch $\mathrm{CPC}$. Sau 120 giờ, khuẩn lạc sống sót được đếm và chuyển sang môi trường lên men để kiểm tra khả năng sinh tổng hợp acarbose và khả năng ức chế $\alpha$-glucosidase. Kết quả cho thấy, có 3 dòng đột biết (Actinoplanes sp. KCTC 9161- L4, L11, L14) ức chế hoạt tính của $\alpha$-glucosidase cao hơn 1,3 lần so với chủng gốc ban đầu và bào tử KCTC 9161 rất nhạy cảm với độc tính của $\mathrm{NTG}, 98 \%$ bào tử chết khi xử lí với $50 \mu \mathrm{g}$ NTG trong 90 phút. Bên cạnh đó, một quy trình hoàn thiện để làm đột biến NTG với Actinoplanes sp. được đề nghị để hỗ trợ những nghiên cứu tiếp theo.
\end{abstract}

Tù khóa: Acarbose, a-glucosidase inhibitor, Actinoplanes sp. KCTC 9161, NTG, fermentation 